\title{
RENCANA KEPEMILIKAN RUMAH BAGI MASYARAKAT BERPENGHASILAN RENDAH (STUDI KASUS KELURAHAN TANJUNGMAS KOTA SEMARANG)
}

\author{
Lulut Indrianingrum ${ }^{1}$
}

1) Program Studi Arsitektur Jurusan Teknik Sipil, Fakultas Teknik, Universitas Negeri Semarang (UNNES)

Kampus Unnes Gd E4, Sekaran, Gunungpati, Semarang 50229, email : lutyindria@gmail.com

\begin{abstract}
Affordable housing programs and banking program has been launched for the implementation of housing programs for Low Income Communities (MBR). MBR characteristics in each region are very diverse make housing programs for this segment is not easy to do the right target. Act 2 of 2001 has mandated that states are obliged to implement the settlement habitable housing for people, especially the MBR. This article will discuss how the public views MBR related to home ownership for families. Aspects related studies include family conditions, financing, location, shape and price residence. The research method used descriptive method with the results of questionnaires to the MBR in Sub Tanjungmas as Village poorest residents in the city of Semarang. The results showed that the respondents have a vision of home ownership by saving and installments. That their visions are still living in and near where you live now or anywhere else that has the same price range. They really understand that in order to obtain environmental conditions and a better home, they have to pay higher prices, then, the standards they use is on the quality of life now and that the location that suitable for them is a house in the kampong area.
\end{abstract}

Keywords : planning, ownership, house, low income groups

\begin{abstract}
Abstrak: Program-program perumahan terjangkau dan program perbankan telah diluncurkan untuk pelaksanaan program perumahan untuk Masyarakat Berpenghasilan Rendah (MBR). Karakteristik MBR di masing-masing daerah yang sangat beragam membuat program perumahan untuk segmen ini tidak mudah dilakukan secara tepat sasaran. Undang-Undang No.2 tahun 2001 telah mengamanatkan bahwa negara wajib menyelenggarakan perumahan permukiman yang layak huni bagi masyarakat khususnya MBR. Artikel ini akan membahas bagaimana pandangan masyarakat MBR terkait kepemilikan rumah bagi keluarganya. Aspek kajian antara lain terkait kondisi keluarga, pembiayaan, lokasi, bentuk tempat tinggal dan harga. Metode penelitian menggunakan metode deskriptif melalui hasil kuisioner kepada MBR di Kelurahan Tanjungmas sebagai Kelurahan dengan penduduk miskin terbanyak di Kota Semarang. Hasil penelitian menunjukkan bahwa responden memiliki visi dalam kepemilikan rumah dengan cara menabung dan mencicil. Bahwa visi mereka adalah masih tinggal disekitar lokasi tempat tinggal sekarang atau tempat lain yang memiliki rentang harga yang sama. Mereka sangat memahami bahwa untuk memperoleh kondisi lingkungan dan rumah yang lebih baik, mereka harus membayar lebih mahal, maka, standar yang mereka gunakan adalah pada kualitas hidup yang dijalani sekarang bahwa lokasi rumah yang cocok untuk mereka adalah rumah di perkampungan.
\end{abstract}

Kata kunci : rencana, kepemilikan, rumah, MBR

\section{PENDAHULUAN}

Perumahan yang layak dan terjangkau menjadi salah satu prioritas yang ditekankan dalam penyelenggaraan perumahan permukiman di Indonesia. Hal tersebut untuk memastikan bahwa masyarakat berpenghasilan rendah (MBR) juga memiliki akses yang sama kepada kepemilikan perumahan dan permukiman. Masyarakat berpenghasilan rendah atau juga dapat disingkat MBR, adalah masyarakat yang mempunyai keterbatasan daya beli sehingga perlu mendapat dukungan pemerintah untuk memperoleh rumah. Karakteristik MBR menurut Permenpera No. 5/PERMEN/M/2007 adalah masyarakat dengan penghasilan dibawah dua juta lima ratus ribu rupiah per bulan. 
Saat ini, MBR menjadi sangat diprioritaskan karena selama ini mereka lemah dalam akses kepada perumahan yang terjangkau. Beberapa skim pembiayaan akhirnya ditawarkan oleh pemerintah untuk mendorong developer menyediakan perumahan yang terjangkau bagi MBR. Program pembangunan rumah susun, pembiayaan menggunakan mekanisme FLPP (Fasilitas Likuiditas Pembiayaan Perumahan) yang saat ini dialihkan dari rumah tapak ke rumah susun diharapkan dapat mendorong percepatan program sejuta rumah (http://ekbis.sindonews.com/read/873931/34/al asan-menpera-alihkan-flpp-ke-rusun1402910414).

Minat pengembang dalam menyediakan rumah murah masih tinggi karena permintaan dari MBR juga tinggi. Hal ini disebabkan karena golongan ini benarbenar membutuhkan rumah dan bukan untuk investasi. Meskipun ada perbaikan dari sisi permintaan dan penawarannya, penyediaan rumah untuk memenuhi backlog tidak mudah karena kompleksitas permasalahan penyelenggaraan perumahan dan permukiman serta kebijakan yang kurang menjawab permasalahan yang ada. Beberapa permasalahan yang muncul adalah terkait supply lahan yang semakin mahal dan terbatas untuk kebutuhan perumahan, pemahaman MBR selama ini belum mewakili karakteristik golongan yang dituju dalam penyelenggaraan perumahan terjangkau, serta rumah susun yang belum diminati oleh masyarakat.

Faktor budaya yang sangat berpengaruh pada minat masyarakat untuk tinggal di rumah susun, budaya bermukim di rumah tapak sangat berbeda dengan budaya di rumah susun. Berdasarkan survei Rumah.com pada tahun 2013 sebagian besar masyarakat Indonesia (70\%) lebih senang membeli rumah tapak dibandingkan dengan rumah susun. Hal tersebut berbeda dengan Singapura yang $80 \%$ masyarakatnya lebih senang membeli apartemen (http://panduanbisnisproperti.com).

Upaya penyediaan rumah untuk MBR ini membutuhkan kajian terkait visi masyarakat dalam kepemilikan rumah yang mereka rencanakan. Artikel ini akan menganalisis rencana MBR terkait rumah yang diinginkan sesuai dengan kapasitas perekonomian mereka. Responden yang dituju adalah MBR yang belum memiliki rumah dan masih tinggal menumpang dengan orang tua atau saudara. Aspek yang dikaji adalah terkait visi untuk memiliki rumah, bentuk kepemilikan rumah, kemampuan mencicil, lokasi yang diminati dan tanggapan terkait rumah susun. Lokasi yang dituju adalah Kelurahan Tanjungmas Kota Semarang sebagai salah satu kelurahan dengan jumlah warga miskin terbesar di Kota Semarang. Metode yang digunakan adalah diskriptif kuantitatif, menggunakan kuisioner yang nantinya dijabarkan secara deskriptif.

\section{MASYARAKAT BERPENGHASILAN RENDAH (MBR)}

Pemahaman mengenai MBR menurut beberapa sumber sangat beragam batasannya khususnya terkait kondisi ekonomi dan sosialnya. Terkait kondisi sosial, menurut Lewis dalam Suparlan, 1984, MBR adalah kelompok masyarakat yang mengalami tekanan ekonomi, sosial, budaya dan politik 
yang cukup lama sehinggga menghasilkan suatu kebudayaan yang disebut budaya miskin. Selain itu, Asian Development Bank (ADB) menyebutkan MBR adalah masyarakat yang tidak memiliki akses dalam proses menentukan keputusan yang menyangkut kehidupannya. Secara sosial mereka tersingkir dari institusi masyarakat. Secara ekonomi terlihat dari rendahnya kualitas sumber daya manusia yang menyebabkan rendahnya tingkat penghasilan mereka. Secara budaya dan tata nilai, mereka terperangkap dalam etos kerja yang rendah, pola pikir pendek dan fatalisme. Serta akses mereka terhadap fasilitas lingkungan yang rendah.

Terkait kondisi ekonomi, batasan penghasilan dijabarkan Permenpera No.5/PERMEN/M/2007, MBR merupakan masyarakat dengan penghasilan dibawah $\mathrm{Rp}$ 2.500.000,- per bulan. Sedangkan dari Program Nasional Pengembangan Sejuta Rumah 2004 menyebutkan bahwa MBR adalah keluarga/masyarakat yang memiliki penghasilan maksimal Rp 1.500.000,-. Pendapat lain yang menunjukkan kriteria penghasilan MBR adalah (Karamoy dalam Budiarjo, 1998) bahwa MBR adalah mereka yang berpenghasilan Rp 10.000,- - Rp. 30.000 per bulan. Dari penjelasan diatas, batasan terkait pendapatan yang sangat mudah dipahami, bahwa MBR adalah mereka yang memiliki penghasilan dibawah 2,5 juta per bulan.

\section{RUMAH UNTUK MBR}

Rumah bagi MBR merupakan hasil dari suatu proses keputusan yang mempertimbangkan berbagai kebutuhan dan kemampuan baik secara ekonomi, sosial dan fisik. Rumah harus memenuhi syarat dekat dengan tempat kerja atau berlokasi di tempat yang berpeluang dalam mendapatkan pekerjaan. MBR tidak terlalu mementingkan kualitas fisik rumah asalkan tetap menjamin kelangsungan kehidupannya, dan juga tidak memandang pentingnya hak-hak penguasaan atas tanah dan bangunan karena rumah dianggap suatu fasilitas (Santoso, et.al,2002:41). Prioritas utama MBR adalah jarak rumah dengan tempat kerja (lokasi) baru, status kepemilikan lahan serta kualitas rumah adalah prioritas berikutnya (Turner (1971) dalam Panudju (1999:9-12).

\section{PROFIL KELUARGA MISKIN KELURAHAN TANJUNGMAS}

Kelurahan Tanjung Mas berada di wilayah Kecamatan Semarang Utara, meliputi areal seluas $323,782 \mathrm{Ha}$. Kelurahan ini tergolong daerah pesisir yang masih terpengaruh kondisi pasang surut dari Laut Jawa. Rob dan tergenangnya kawasan karena air laut menjadi pemandangan sehari-hari. Jumlah penduduk Kelurahan Tanjungmas sebanyak 128 ribu jiwa, jumlah warga miskinnya sebanyak 11.859 jiwa atau sebesar $9 \%$. Berikut ini adalah profil keluarga miskin di Kecamatan Semarang Utara yang diambil dari data SIMGAKIN tahun 2013.

Tabel 1. Keluarga Miskin Kecamatan Semarang Utara

\begin{tabular}{lccccccr}
\hline \multirow{2}{*}{ Kelurahan } & \multicolumn{2}{c}{ Hampir Miskin } & \multicolumn{2}{c}{ Miskin } & \multicolumn{2}{c}{$\begin{array}{c}\text { Sangat } \\
\text { Miskin }\end{array}$} \\
\cline { 2 - 8 } & KK & Jiwa & KK & Jiwa & KK & Jiwa \\
\hline Bandarharjo & 2.244 & 7.731 & 469 & 1.520 & 1 & 2 \\
\hline Bulu Lor & 1.053 & 3.650 & 267 & 978 & 2 & 8 \\
\hline Plombokan & 711 & 2.408 & 358 & 1.281 & - & - \\
\hline Purwosari & 846 & 2.721 & 80 & 255 & - & - \\
\hline
\end{tabular}




\begin{tabular}{|c|c|c|c|c|c|c|}
\hline Kuningan & 945 & 3.248 & 145 & 453 & 1 & 3 \\
\hline Penggunglor & 55 & 165 & 3 & 13 & - & - \\
\hline $\begin{array}{l}\text { Panggung } \\
\text { kidul }\end{array}$ & 678 & 2.286 & 115 & 379 & - & - \\
\hline Tanjungmas & 2.762 & 9.243 & 787 & 2.612 & 1 & 4 \\
\hline Dadapsari & 943 & 3.215 & 210 & 732 & - & - \\
\hline $\begin{array}{l}\text { Jml Jiwa } \\
\text { Per Kec. }\end{array}$ & 10.237 & 34.667 & 2.434 & 8.223 & 5 & 17 \\
\hline
\end{tabular}

Sumber : SIMGAKIN 2013

Kawasan Kelurahan Tanjung Mas mencakup dua wilayah lingkungan/kampung, yaitu Lingkungan/ Kampung Tambak Lorok di bagian Utara dan Lingkungan/Kampung Sidodadi di bagian Selatan. Lokasi Pembangkit Indonesia Power yang cukup luas merupakan bagian dari wilayah admininstrasi kelurahan ini sehingga lokasi permukiman cenderung terpisah cukup jauh dan adanya jalan arteri primer membelah kelurahan ini menjadi dua lokasi. Masalah lingkungan yang cukup sulit penanganannya sampai saat ini adalah masalah rob dan penurunan muka tanah/ land settlement. Kondisi rumah dan infrastruktur menjadi buruk karena selalu tergenang air laut jika masa pasang air laut terjadi.

\section{HASIL : RENCANA KEPEMILIKAN RUMAH BAGI MBR}

Penelitian ini berfokus pada bagaimana MBR memiliki rencana dalam mengakses rumah didasarkan atas kondisi perekonomian keluarganya. Pada dasarnya MBR yang menjadi responden memiliki visi terhadap kepemilikan rumah. Mereka memiliki alokasi pembiayaan rumah dan memiliki keinginan memiliki rumah namun dengan tingkat keterjangkauan yang berbeda-beda.

Sebagian besar responden memiliki keinginan memiliki rumah dalam bentuk rumah milik bukan sewa dengan cara menabung. Jawaban ini cukup menarik karena dengan struktur pendapatan yang rendah (rata-rata dibawah 1 juta/ bulan), mereka memiliki visi untuk memiliki rumah tanpa sewa. Selain itu, pilihan untuk menabung merupakan keputusan yang sangat kreatif karena mereka sama sekali tidak menggunakan opsi cicilan bank.

Keputusan ini terjawab karena lebih dari $90 \%$ responden memilih untuk memiliki tempat tinggal di perkampungan daripada bentuk lain seperti perumahan atau rumah susun. Untuk MBR, visi kepemilikan rumah didasarkan atas kondisi yang mereka alami sekarang. Pada saat ini, responden bertempat tinggal di perkampungan dan mereka menyatakan nyaman dengan kondisi sosial di perkampungan. Mereka juga menyatakan bahwa rumah di perkampungan memiliki harga yang terjangkau untuk mereka.

Perkampungan yang seperti apa yang terjangkau untuk mereka, hal ini terjawab pada pernyataan tentang harga rumah yang sanggup mereka jangkau. Dari jawaban harga rumah yang terjangkau, lebih dari $70 \%$ menjawab antara 50 - 100 juta. Rata-rata dari rentang ini menjawab pada kisaran 100 juta. Setelah didalami, ternyata harga rumah disekitar lokasi tempat tinggal responden adalah pada kisaran jawaban mereka. Bagi responden MBR yang memiliki struktur pendapatan yang lebih tinggi, sebagian besar terdapat di Kampung Sidodadi, rata-rata jawaban harga rumah adalah diatas 100 juta.

Jika dianalisa dari sisi kemampuan mencicil, sebagian besar menjawab cicilan pada kisaran 500 ribu per bulan. Jumlah cicilan ini merupakan rata-rata harga sewa perbulan dilokasi mereka tinggal. Cicilan diatas 
1 juta tidak menjadi pilihan mereka karena sudah tidak sesuai dengan jumlah pendapatan mereka. Dengan uang 500 ribu per bulan, sebenarnya MBR sudah dapat memiliki rumah susun sewa dengan kondisi lingkungan yang lebih baik. Namun rumah susun sangat tidak diminati oleh responden.

Melalui komparasi ini, dapat diketahui bahwa visi mereka adalah masih tinggal disekitar lokasi tempat tinggal sekarang atau tempat lain yang memiliki rentang harga yang sama. Mereka sangat memahami bahwa untuk memperoleh kondisi lingkungan dan rumah yang lebih baik, mereka harus membayar lebih mahal. Oleh karena itu, standar yang mereka gunakan adalah pada kualitas hidup yang dijalani sekarang ini untuk memiliki rumah di perkampungan.

Rumah susun baik sewa maupun milik tidak menjadi pilihan bagi responden karena hampir tidak ada yang memilih rumah susun sebagai visi kepemilikan rumah. Sebagian besar responden enggan tinggal di rumah susun karena tidak nyaman, sempit dan kesulitan untuk sirkulasi karena harus naik turun tangga. Hal ini menunjukkan bahwa kebijakan rumah susun perlu dititikberatkan dalam proses sosialisasi secara sosiologi kemasyarakatan karena justru transformasi secara sosial ini yang mempengaruhi preferensi MBR terhadap rumah susun.

Meskipun sebagian besar memilih menabung untuk membeli rumah, pilihan pembiayaan yang mereka inginkan adalah mencicil (76\%), meskipun jumlah responden yang menjawab kontan juga cukup signifikan (19\%). Jika dilihat dari pilihan jawaban mencicil lewat bank ternyata hanya $12 \%$, hal ini dapat diketahui bahwa pilihan mencicil mereka tidak melalui bank. Namun jika jawaban ini dikomparasi dengan pilihan cara mencicil responden, hal ini menjadi sangat bertolak belakang, karena justru $60 \%$ responden yang diberikan pilihan lokasi mencicil, mereka memilik bank daripada koperasi dan kantor pos. Hal ini secara kasar dapat diartikan bahwa MBR ketika tidak dihadapkan pada pilihan mencicil, mereka cenderung memilih menabung daripada berhutang. Namun ketika dihadapkan pada pilihan mencicil atau berhutang, mereka memilih bank sebagai institusi yang terpercaya.

Dari uraian diatas, nampak bahwa pilihan responden MBR sangat terpengaruh oleh kondisi rumah dan lingkungan yang saat ini ditempati. Standar yang mereka gunakan untuk rumah mereka adalah sama seperti lingkungan tempat tinggal mereka sekarang.

\section{KESIMPULAN}

1. MBR ketika tidak dihadapkan pada pilihan mencicil, mereka cenderung memilih menabung daripada berhutang. Namun ketika dihadapkan pada pilihan mencicil atau berhutang, mereka memilih bank sebagai institusi yang terpercaya.

2. Bahwa visi mereka adalah masih tinggal disekitar lokasi tempat tinggal sekarang atau tempat lain yang memiliki rentang harga yang sama. Mereka sangat memahami bahwa untuk memperoleh kondisi lingkungan dan rumah yang lebih baik, mereka harus membayar lebih mahal. Oleh karena itu, standar yang mereka gunakan adalah pada kualitas hidup yang dijalani sekarang ini untuk memiliki rumah di perkampungan. 
3. Rumah susun baik sewa maupun milik tidak menjadi pilihan bagi responden karena hampir tidak ada yang memilih rumah susun sebagai visi kepemilikan rumah.

4. Rumah susun masih dianggap kurang cocok bagi masyarakat karena kurang nyaman dalam pergerakan karena harus naik turun dan proses transformasi sosial yang relatif belum berlangsung dengan baik.

\section{DAFTAR PUSTAKA}

Budiharjo, Eko. 1998. Sejumlah Masalah Permukiman Kota. Bandung. Penerbit Alumni.

Menteri Negara Perumahan Rakyat, 1994, Keputusan Menpera Nomor: 06/KPT/1994 tentang Pedoman Umum Pembangunan Perumahan Bertumpu pada Kelompok.

Panudju, B, 1999, Pengadaan Perumahan Kota Dengan Peran Serta Masyarakat Berpenghasilan Rendah, Penerbit Alumni.Bandung.

Santoso, Jo, Budi P. Iskandar, dan Parwoto (ed). 2002, Sistem Perumahan Sosial di Indonesia. Jakarta. Pusat Studi Perkotaan Universitas Indonesia Esa Unggul.

SNI 03-1733-2004 tentang Tata Cara Perencanaan Lingkungan Perumahan di Perkotaan.

Suparlan, Pasurdi. 1984. Kebudayaan Kemiskinan dalam Buku Kemiskinan Perkotaan. Jakarta. Penerbit Sinar Harapan

Surat Keputusan Menteri KIMPRASWIL, No. 217 / KPTS / M / 2002 tentang Kebijaksanaan dan Strategi Nasional Perumahan dan Permukiman (KSNPP)

Undang-Undang Republik Indonesia Nomor 1 Tahun 2010 tentang Perumahan dan Permukiman

\section{http://www.kimpraswil.go.id}

http://ekbis.sindonews.com/read/873931/34/al asan-menpera-alihkan-flpp-ke-rusun1402910414 